\title{
Selection of Hydrological Model for Waterborne Release
}

by

A. Blanchard

Westinghouse Savannah River Company

Savannah River Site

Aiken, South Carolina 29808

T. I. Brown Jr.

WSMS

D. R. Marx

WSMS

DOE Contract No. DE-AC09-96SR18500

This paper was prepared in connection with work done under the above contract number with the U.S.

Department of Energy. By acceptance of this paper, the publisher and/or recipient acknowledges the U. S.

Government's right to retain a nonexclusive, royalty-free license in and to any copyright covering this paper, along with the right to reproduce and to authorize others to reproduce all or part of the copyrighted paper. 


\section{Selection of Hydrological Model for Waterborne Release (U)}

T.I. Brown Jr., D.R. Marx

December 1998

Westinghouse Savannah River Company Aiken, SC 29808
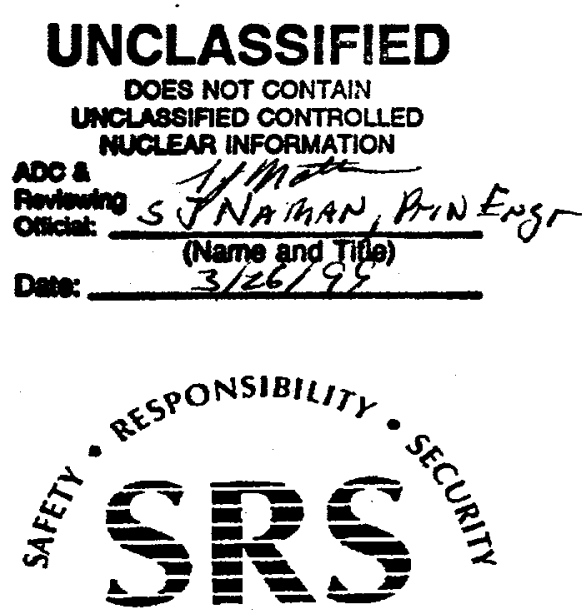

SAVANNAH RIVER SITE

PREPARED FOR THE U.S. DEPARTMENT OF ENERGY UNDER CONTRACT NO. DE-AC09-96SR18500 
Keywords:

Waterborne Release

Emergency Planning

Release Duration

Consequence analysis

Hydrological Models

\section{Selection of Hydrological Model for Waterborne Release (U)}

T.I. Brown Jr., D.R. Marx

December 1998

Westinghouse Savannah River Company Aiken, SC 29808

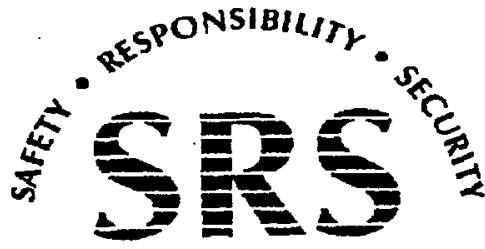

SAVANNAH RIVER SITE

PREPARED FOR THE U.S. DEPARTMENT OF ENERGY UNDER CONTRACT NO. DE-AC09-96SR18500 


\section{DISCLAIMER}

This report was prepared as an account of work sponsored by an agency of the United States Government. Neither the United States Government nor any agency thereof, nor any of their employees, makes any warranty, express or implied, or assumes any legal liability or responsibility for the accuracy, completeness, or usefulness of any information, apparatus, product, or process disclosed, or represents that its use would not infringe privately owned rights. Reference herein to any specific commercial product, process, or service by trade name, trademark, manufacturer, or otherwise does not necessarily constitute or imply its endorsement, recommendation, or favoring by the United States Government or any agency thereof. The views and opinions of authors expressed herein do not necessarily state or reflect those of the United States Government or any agency thereof.

This report has been reproduced directly from the best available copy.

Available to DOE and DOE contractors from the Office of Scientific and Technical Information, P.O. Box 62, Oak Ridge, TN 37831; prices available from (615) 576-8401.

Available to the public from the National Technical Information Service, U.S. Department of Commerce; 5285 Port Royal Road, Springfield, VA 22161. 


\section{DISCLAIMER}

Portions of this document may be illegible in electronic image products. Images are produced from the best available original document. 
Project: Emergency Preparedness Issues for Waterborne Releases

Document: WSRC-TR-98-00448

Title:

Selection of Hydrological Models for Waterborne Release (U)

WSMS Approvals:

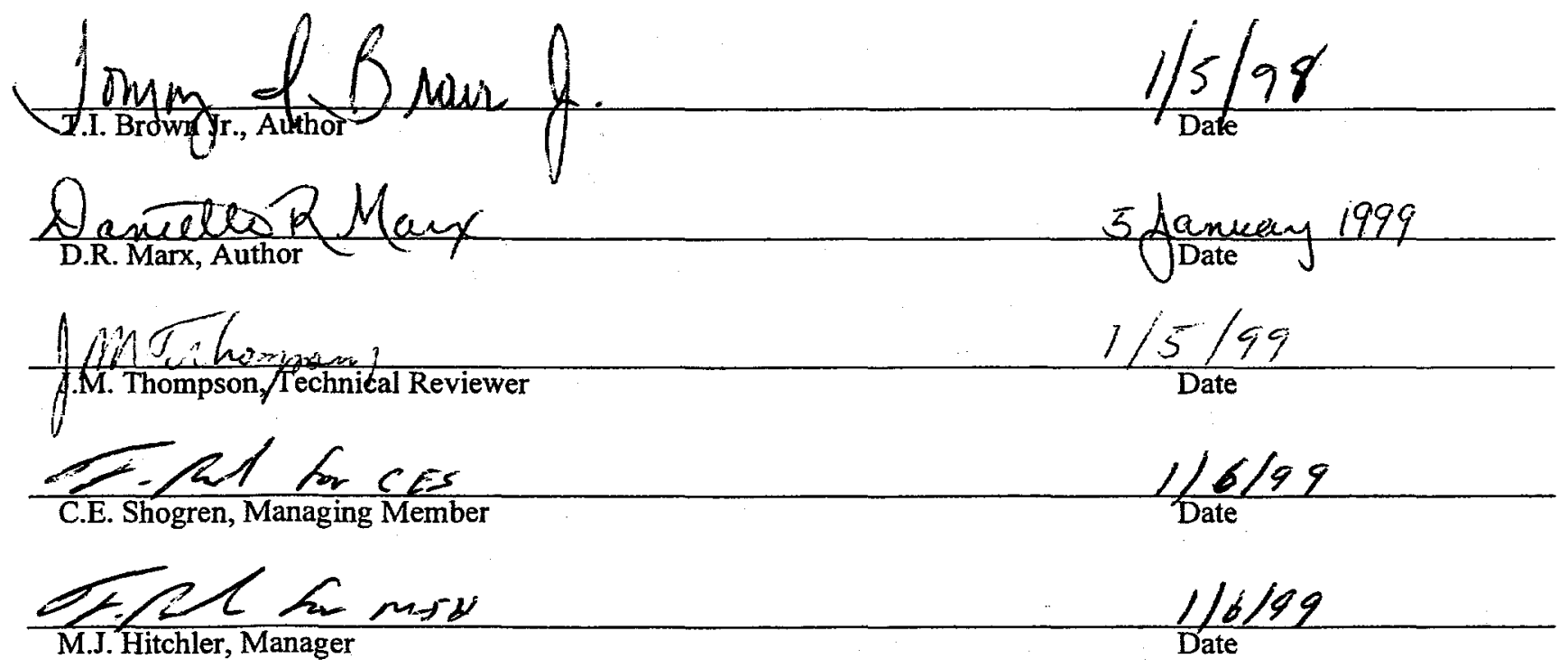


This Page Intentionally Left Blank 


\section{EXECUTIVE SUMMARY}

The Savannah River Site (SRS) evaluated and tested its hydrological dose codes. The testing determined the appropriate model for use in future modeling regarding the effects of hydrological releases to the Savannah River on downstream populations. Testing and evaluation of the SRS hydrological dose codes included identification of constraints, assessment of code flexibility, and total cost consideration. Evaluation of postulated releases, in a manner consistent with that of DOE/EH-0173T and DOE Orders 5400.1 and 5400.5, provides a perspective on the potential consequences that aqueous releases from SRS facilities may have on downstream users of the Savannah River. Guidelines for evaluation of contaminant concentration levels in water are the Environmental Protection Agency Safe Drinking Water Standards (EPA 1998) and the Food and Drug Administration Derived Intervention Levels for Accidental Radioactive Contamination of Human Food and Animal Feeds (FDA 1998).

Presented are the criteria used to select codes that model surface water release of contaminants to the environment. Two liquid release scenarios were analyzed to perform a comparison between the SRS hydrological dose codes STREAM2 and LADTAP XL. The releases are assumed to be introduced into the Savannah River via an accidental spill of contaminated water. The entire contents of the spill are assumed to reach the river. Based on an analysis of the radionuclide water concentrations reported by the two codes and the aspects desired in the code for the future study, STREAM2 is recommended for use. 
$\because \quad . \quad \therefore$

This Page Intentionally Left Blank 


\section{Table of Contents}

1.0 INTRODUCTION................................................................................... 1

2.0 BACKGROUND .................................................................................................

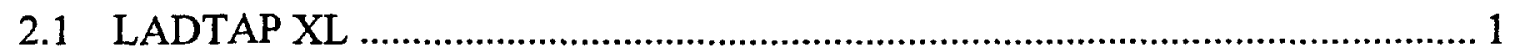

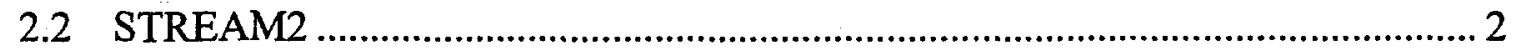

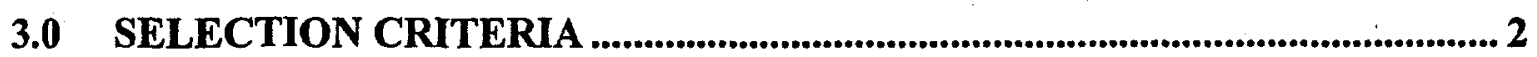

4.0 SCENARIOS USED FOR MODEL TESTING ................................................... 3

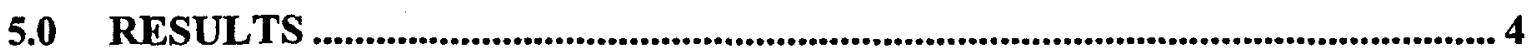

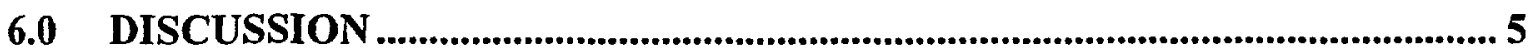

7.0 SUMMARY ............................................................................................................................ 7

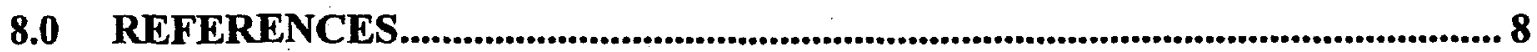

9.0 APPENDIX - SCENARIOS AND ANALYSIS PARAMETERS FOR THE FINAL WATERBORNE RELEASE EXAMINATION........................................................... 10

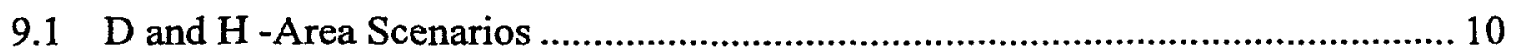

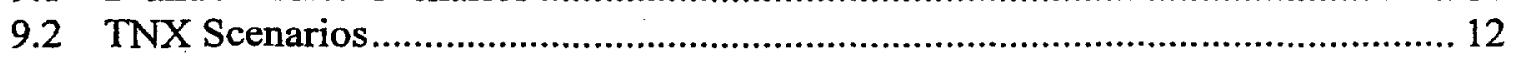




\section{List of Tables}

Table 1 Isotopic Composition of the Dilute Supernate at 5 year Maturity ................ 4

Table 2 Water Concentration for H-Area Release................................. 5

Table 3 Water Concentration for D-Area Release................................... 5

Table 4 Hydrological Dose Model Selection Criteria................................6

Table 5 H-Area Design Basis Source Term for Liquid Runoff..........................11

Table 6 H-Area Beyond Design Basis Source Term for Liquid Runoff.................. 12 


\subsection{INTRODUCTION}

Following a request from the States of South Carolina and Georgia, downstream radiological consequences from postulated accidental aqueous releases at the Savannah River Site (SRS) will be examined. These accidental events include postulated Design Basis (DB) and Beyond Design Basis (BDB) Accidents at three SRS nonreactor nuclear facilities. This evaluation will aid in determining the potential impacts of liquid releases to downstream populations on the Savannah River.

Two SRS surface spill runoff hydrological dose codes are currently available. These two codes, LADTAP XL and STREAM2, are both maintained by Savannah River Technology Center (SRTC) personnel. A prerequisite for examining the SRS DB and BDB accidents is determination of the appropriate code for use in the evaluation. The decision on which hydrological modeling code to use will be based upon testing and evaluation that includes identification of constraints, assessment of code flexibility, and total cost consideration. Evaluation of postulated releases, in a manner consistent with that of DOE/EH-0173T (DOE 1991) and DOE Orders 5400.1 and 5400.5 (DOE 1990, DOE 1993), provides a perspective on the potential consequences that aqueous releases from SRS facilities may have on downstream users of the Savannah River. The purpose of this report is to evaluate the two available models and determine the appropriate model for use in following waterborne release analyses. Additionally, this report will document the DB and BDB accidents to be used in the future study.

\subsection{BACKGROUND}

Evaluation of SRS DB and BDB accidents involving waterborne releases requires the use of a hydrological model. Two SRS aqueous modeling codes, LADTAP XL and STREAM2, will be analyzed for applicability to the future study. For comparison of the models, two accident scenarios have been identified in Section 3.1 and will be modeled with each code. For acute waterborne releases, immersion and the consumption of contaminated fish are beyond the present design parameters of the two hydrological dose codes. The ingestion pathway modeling in acute waterborne releases is expected to be dominant, thus decreasing the importance of including other pathways within the models. The issue of including immersion and consumption of contaminated fish pathways following an acute release could be explored under a separate project. A discussion of LADTAP XL and STREAM2 follows.

\section{$2.1 \quad$ LADTAP XL}

LADTAP XL is an electronic EXCEL spreadsheet designed to model chronic aqueous releases and is based on U.S. Nuclear Regulatory Guide 1.109 (USNRC 1977a): LADTAP XL can be used to predict the radiological consequences to the maximum offsite individual (MOI) and affected populations following postulated chronic aqueous discharges to streams on SRS. Environmental pathways incorporated in LADTAP XL include external exposure resulting from recreational activities on the Savannah River and ingestion of water, fish, and invertebrates of Savannah River origin (Hamby 1991). 
LADTAP XL assumes a constant release over a period of one year. Nuclide concentrations in the Savannah River are estimated by diluting annual releases in a volume of water equal to the total annual river flow without taking into account nuclide depletion other than radioactive decay (Simpkins 1998). Dose predictions are calculated assuming constant annual intake and usage rates for water consumption, fish consumption, and other river activities.

To use LADTAP XL for acute releases, a minimum daily flow rate is used which serves to minimize dilution and maximize concentration. The only pathway appropriate for use with acute releases is the ingestion water pathway. The fish ingestion pathway assumes that the concentration in the fish is in equilibrium with the water concentration. In an accident situation, this would not be the case and is thus not appropriate for inclusion in acute release scenarios. Recreational pathways are not considered for acute releases (Simpkins 1998).

\section{$2.2 \quad$ STREAM2}

STREAM2 is the SRS Weather Information and Display System (WINDS) emergency response hydrological dose code (Chen 1995, Chen 1996a, Chen 1996b). STREAM2 is an aquatic response computer program designed to model the transport of pollutants from a release point within SRS to various points downstream on the Savannah River. STREAM2 is a modified version of STREAM. STREAM uses an algebraic equation to approximate the solution of the one dimensional advective transport differential equation. To correct the problem of spurious oscillations in the concentration profile when modeling long duration releases in STREAM, STREAM2 incorporates the U.S. Environmental Protection Agency (EPA) WASP5 code to replace the transport and diffusion module of STREAM (Chen 1998a). The WASP5 code is a water quality analysis program that simulates one-dimensional pollutant transport and fate through surface water. Additional input files describing the geometry of the pollutant pathway from the release point to the coastal area and the stream/river flow conditions are used in STREAM2 for simulations (Chen 1998b).

STREAM2 is composed of three modules: the calculation, pre-processor, and post-processor modules. The pre-processor module user interface consists of the time, date, type, location, calculation units, amount, and duration of the release. The input data from the user is transferred from the pre-processor to the calculation module, which calculates the pollutant concentrations and transport time at downstream locations. The post-processor module displays the output data from the pollutant concentrations and transport times on the computer screen in graphical and tabular form.

\subsection{SELECTION CRITERIA}

Several technical factors enter into the selection of hydrological dose codes. The code must be able to give temporal information, specifically time-to-impact outputs with varying flow rates and transport times to downstream receptors, and perform instantaneous release calculations. Ideally, the code should be flexible enough to calculate concentration following both chronic and acute aqueous releases to the environment. The model should be among, or consistent with, those models that will actually be used or available following a release and should have adequate documentation. The model should have low costs associated with acquisition, training, 
execution, and minimal constraints. Calculation of contaminant concentration and radiological dose downstream are important outputs. Calculation of radiological doses to the public resulting from the ingestion of contaminated water must be consistent with guidance DOE/EH-0071 (DOE 1988) for Internal Dose Conversion Factors for Calculation of Dose to the Public. All individual and population doses are based on the assumption that liquids discharged from SRS facilities are completely mixed in the river before reaching the potential pathways. The dose calculations are also based on the assumptions that all radionuclides are conserved during transport except for radiological decay of target isotopes. Therefore, factors such as hold up time and/or biological filtration in the intervening wetland during transport to the Savannah River are not incorporated. Guidelines used for evaluation of contaminant concentration levels in water are the Environmental Protection Agency Safe Drinking Water Standards (EPA 1998) and the Food and Drug Administration Derived Intervention Levels for Accidental Radioactive Contamination of Human Food and Animal Feeds (FDA 1998).

If both models are found to meet the technical factors, preference will be given to the simplest model(s), in accordance with scientific consensus (NCRP 1996). Choosing the least complex model has several advantages. In general, the time needed to construct input files and run a simple model is shorter. Fewer input parameters reduce the likelihood of a transcription error. Additionally, the results from simple models may be more easily verified by hand calculations than calculations from complex models. In summary, the selection of the hydrological modeling code for acute surface water releases must consider the capabilities, availability, familiarity, simplicity, and cost of the code. The model selection criteria listed above are summarized in Section 6.0, Table 4.

\subsection{SCENARIOS USED FOR MODEL TESTING}

In order to determine the appropriate code for use in the hydrological modeling examination, aqueous release scenarios for D-Area and H-Area were analyzed by both the STREAM2 and LADTAP XL codes. Bounding source terms from current facility Authorization Basis documents were used in selection of the two scenarios (Hope 1998). Radionuclide concentrations at three locations on the Savannah River - the river outfall, the intersection with Highway 301, and the Savannah, GA, water supply - were calculated using both modeling codes and compared. For both releases it was assumed that the radionuclides are introduced into the Savannah River via an accidental spill of contaminated water and that the entire contents of the spill reach the river. The $\mathrm{D}$ and $\mathrm{H}$ area accident scenarios used for model testing are described below.

In D-Area, the bounding radiological hazard is stored reactor moderator that is contaminated with tritium oxide. For the D-Area Heavy Water Facility accidental release scenario, the source term is assumed to be $2.58 \times 10^{+6} \mathrm{Ci}$ of tritium oxide (HTO). Using the given concentration of 11 curies per liter, the release would be $6.24 \times 10^{+4}$ gallons of moderator.

The second scenario is an assumed release from the H-Area Tank Farm resulting from an evaluation basis earthquake event. The source term for the liquid surface water release is $1.6 \times$ $10^{+6}$ gallons of dilute supernate. The isotopic composition of the dilute supernate at five years maturity is given in Table 1 . 
Table 1 Isotopic Composition of the Dilute

Supernate at five year Maturity

\begin{tabular}{|l|l|}
\hline Isotope & Ci/Gallon \\
\hline Sr-90 & $1.3 \mathrm{E}-03$ \\
\hline $\mathrm{Ru}-106$ & $1.8 \mathrm{E}-01$ \\
\hline $\mathrm{Cs}-134$ & $7.2 \mathrm{E}-01$ \\
\hline $\mathrm{Cs}-137$ & $5.0 \mathrm{E}+00$ \\
\hline $\mathrm{Pu}-238$ & $6.5 \mathrm{E}-03$ \\
\hline
\end{tabular}

The duration of release for D-Area is assumed to be instantaneous. Both an instantaneous release and a 24- hour release are assumed for $\mathrm{H}$-Area incidents.

The aqueous release scenarios that will be modeled following determination of the appropriate modeling code are located in the Appendix.

\subsection{Results}

Radionuclide concentrations were calculated using both LADTAP XL and STREAM2. Table 2 presents the calculated concentrations at the Highway 301 intersection and the Savannah, GA, water supply for the H-Area Tank Farm release. The LADTAP XL results used a 24-hour release duration, while the STREAM2 results were calculated for both an instantaneous and a 24-hour release. Flow rates in the STREAM2 calculations were assumed to be constant at both Highway 301 and Savannah, GA, while LADTAP calculations used a varying flow rate at the two points. The LADTAP XL 24-hour adjusted flow rate column uses the STREAM2 flow rate for ease in comparison.

Table 3 presents the results for the postulated release from D-Area. STREAM2 calculations are shown for peak concentrations at three downstream locations and LADTAP calculations are for the 24-hour concentrated release duration. Since LADTAP XL is not designed to handle releases of such a short duration, results less than a 24-hour release duration are not reported for this scenario. LADTAP XL results could be modified using calculation data from U.S. Nuclear Regulatory Commission Regulatory Guide 1.113 (NRC 1977b) to give results for instantaneous releases, but this development work is beyond the scope of this project. 
Table 2 Water Concentration for H-Area Release

\begin{tabular}{|c|c|c|c|c|c|c|c|}
\hline & \multicolumn{3}{|c|}{ Highway 301 conc. $\mathrm{Ci} / \mathrm{L}$} & \multicolumn{4}{|c|}{ Savannah, GA, conc. $\mathrm{C} / \mathrm{L}$} \\
\hline & LADTAP XL & STR & AM2 & $\overline{\mathbf{L A D}}$ & $\mathbf{P \mathbf { P X L }}$ & STF & AM2 \\
\hline Radionuclide & 24-hr & $\begin{array}{l}\text { Inst. } \\
\text { Peak }\end{array}$ & $\begin{array}{l}\text { 24-hr } \\
\text { Peak }\end{array}$ & 24-hr & $\begin{array}{c}\text { 24-hr } \\
\text { Adjusted } \\
\text { Flow }\end{array}$ & $\begin{array}{l}\text { Inst. } \\
\text { Peak }\end{array}$ & $\begin{array}{c}\text { 24-hour } \\
\text { Peak }\end{array}$ \\
\hline Sr-90 & $1.20 \mathrm{E}-07$ & $1.90 \mathrm{E}-07$ & $1.14 \mathrm{E}-07$ & $9.60 \mathrm{E}-08$ & $1.20 \mathrm{E}-07$ & $1.74 \mathrm{E}-07$ & $1.12 \mathrm{E}-07$ \\
\hline Ru-106 & $1.70 \mathrm{E}-05$ & $2.64 \mathrm{E}-05$ & $1.58 \mathrm{E}-05$ & $1.30 \mathrm{E}-05$ & $1.63 \mathrm{E}-05$ & $2.42 \mathrm{E}-05$ & $1.55 \mathrm{E}-05$ \\
\hline Cs-134 & $6.60 \mathrm{E}-05$ & $1.05 \mathrm{E}-04$ & $6.32 \mathrm{E}-05$ & $5.30 \mathrm{E}-05$ & $6.63 \mathrm{E}-05$ & $9.65 \mathrm{E}-05$ & $6.17 \mathrm{E}-05$ \\
\hline Cs-137 & $4.60 \mathrm{E}-04$ & $7.33 \mathrm{E}-04$ & $4.39 \mathrm{E}-04$ & $3.70 \mathrm{E}-04$ & $4.63 \mathrm{E}-04$ & $6.71 \mathrm{E}-04$ & $4.29 \mathrm{E}-04$ \\
\hline Pu-238 & $6.00 \mathrm{E}-07$ & $9.52 \mathrm{E}-07$ & $5.71 \mathrm{E}-07$ & $4.80 \mathrm{E}-07$ & $6.00 \mathrm{E}-07$ & $8.72 \mathrm{E}-07$ & $5.58 \mathrm{E}-07$ \\
\hline
\end{tabular}

Table 3 Water Concentration for D-Area Release

\begin{tabular}{|l|c|c|c|c|}
\hline & $\begin{array}{c}\text { LADTAP } \\
\text { conc. (Ci/L) }\end{array}$ & \multicolumn{3}{|c|}{ STREAM/2 conc. (Ci/L) } \\
\hline Radionuclide & $24 \mathrm{hr}$ & $\begin{array}{c}\text { B. Dam Inst. } \\
\text { Peak }\end{array}$ & $\begin{array}{c}\text { Hwy 301 } \\
\text { Inst. Peak }\end{array}$ & $\begin{array}{c}\text { Savannah } \\
\text { Inst. Peak }\end{array}$ \\
\hline H-3 & $1.50 \mathrm{E}-04$ & $1.44 \mathrm{E}-03$ & $9.76 \mathrm{E}-04$ & $6.30 \mathrm{E}-04$ \\
\hline
\end{tabular}

\subsection{Discussion}

Based on the concentration data provided in Section 5.0 and the selection criteria described in Section 3.0, a hydrological modeling code for use in future waterborne release modeling must be chosen. Table 4 presents a listing of the selection criteria used to compare LADTAP XL and STREAM2.

Both LADTAP XL and STREAM2 are capable of calculating radionuclide concentrations following chronic (1 year) and acute (24-hour) releases. However, only STREAM2 is capable of calculating concentrations following an instantaneous release. The concentration values calculated within the codes are average values for LADTAP XL and peak values with STREAM2. LADTAP XL is capable of calculating both concentration and dose while STREAM2 only calculates concentration. Documentation comparing the modeling code to actual measurements on the Savannah River is available for STREAM2 but not for LADTAP XL. Additionally, STREAM 2 is more flexible than LADTAP XL and also includes temporal data while LADTAP XL is more simplistic. There is not a substantial difference in costs associated with acquisition, training, and execution for the two models. Both models are consistent with DOE guidelines.

The one-dimensional diffusion modeled in STREAM2 provides more realistic values, especially for short duration releases. The lack of temporal information in LADTAP XL precludes calculation of time-to-impact values. Considering the importance of these values and the comparison of the models provided in Table 4 , it is recommended that STREAM2 be used in future waterborne release modeling and examination. 
Table 4 Hydrological Dose Model Selection Criteria

\begin{tabular}{|c|c|c|}
\hline \multicolumn{1}{|c|}{ Selection Criteria } & STREAM2 & LADTAP XL \\
\hline Scenario Testing and Evaluation & $\checkmark$ & \\
\hline Code Flexibility & $\checkmark$ & \\
\hline 1. Chronic (1yr) aqueous release & $\checkmark$ & $\checkmark$ \\
\hline 2. Acute (24hr)aqueous release & $\checkmark$ & $\checkmark$ \\
\hline 3. Instantaneous aqueous release & $\checkmark$ & \\
\hline Provide Temporal Data & $\checkmark$ & \\
\hline 1. Transport Times & $\checkmark$ & \\
\hline Calculate Time to Impact Data & $\checkmark$ & \\
\hline 1. Radiological dose & & \\
\hline 2. Average concentration & & $\checkmark$ \\
\hline 3. Peak concentration & & $\checkmark$ \\
\hline 5. Average flow rates & $\checkmark$ & \\
\hline 6. Minimum flow rates & $\checkmark$ & $\checkmark$ \\
\hline $\begin{array}{l}\text { Low Costs associated with acquisition, training, and } \\
\text { execution. }\end{array}$ & $\checkmark$ & $\checkmark$ \\
\hline 1. Model Familiarity & $\checkmark$ & \\
\hline 2. Model Simplicity & $\checkmark$ & \\
\hline 3. Model Availability & $\checkmark$ & $\checkmark$ \\
\hline 4. Adequate Model Documentation & $\checkmark$ & $\checkmark$ \\
\hline 5. Quality Assurance Capabilities & $\checkmark$ & $\checkmark$ \\
\hline Available for use following a release to the environment & $\checkmark$ & $\checkmark$ \\
\hline Consistent with DoE Guidelines & $\checkmark$ & \\
\hline
\end{tabular}




\subsection{SUMMARY}

Two SRS hydrological modeling codes, STREAM2 and LADTAP XL, have been examined for use in future waterborne release studies. STREAM2, the Weather Information and Display System (WINDS) emergency response hydrological code, is an aquatic response computer program designed to model the transport of pollutants from a release point within SRS to various points downstream on the Savannah River. STREAM2 has the flexibility to give outputs for instantaneous, chronic, and acute aqueous releases to the environment. LADTAP XL is a simplistic dilution model capable of calculating concentrations for chronic and 24-hour releases. A comparison of the two scenarios shows that the differences between the two codes for a 24hour release are minimal. Considering the similarity in calculated concentrations and the temporal information available with STREAM2, it is recommended that STREAM2 be used for future waterborne release analysis. 


\subsection{REFERENCES}

K-F Chen (1995). Revised STREAM Code and WASP5 Benchmark (U), Westinghouse Savannah River Company, Aiken, SC, WSRC-RP-95-598.

K-F Chen (1996a). Critical Contaminant/Critical Pathway Analysis- Surface Water Transport for Nonradioactive Contaminants (U), Westinghouse Savannah River Company, Aiken, SC, WSRC-RP-96-555.

K-F Chen (1996b). Revised STREAM Code Benchmarking with 1991 K-Reactor Tritiated Aqueous Release Incident (U), Westinghouse Savannah River Company, Aiken, SC, WSRCRP-96-80.

K-F Chen (1998a). STREAM2 for SRS Aqueous Release Emergency Response (U), Westinghouse Savannah River Company, Aiken, SC, WSRC-TR-98-00234.

K-F Chen (1998b). Inter-Office Memorandum to D.R. Marx, "Hydrological Modeling for Waterborne Releases from D and H Areas (U)," Westinghouse Savannah River Company, Aiken, SC, SRT-NTS-980285 (16 November 1998).

L.L. Clifton (1998). Waterborne Release Monitoring and Surveillance Programs at the Savannah River Site, Westinghouse Savannah River Company, Aiken, SC, WSRC-TR-9800411.

C.D. Cope (1996). Beyond Design Basis Accident Analysis for a Seismic Event (U), Westinghouse Savannah River Company, Aiken, SC, S-CLC-G-00108.

DOE (1988). , Internal Dose Conversion Factors for Calculation of Dose to the Pubic. U.S. Department of Energy Office of Environmental Management, Washington, DC, DOE/EH0071 .

DOE (1990). General Environmental Protection Program. U.S. Department Energy Order 5400.1, Washington, DC.

DOE (1991). Environmental Regulatory Guide for Radiological Effluent Monitoring and Environmental Surveillance at U.S. Department of Energy Installations. U.S. Department of Energy, Washington, DC, DOE/EH-0173T.

DOE (1993). Radiation Protection of the Public and the Environment. U.S. Department of Energy Order 5400.5, Washington, DC.

DOE (1996). Natural Phenomena Hazards Design and Evaluation Criteria for Department of Energy Facilities. U.S. Department of Energy, Washington, DC, DOE-STD-1020-94, Change 1.

EPA (1998). National Primary Drinking Water Regulations. Environmental Protection Agency 40 CFR 141, Washington, DC. 
FDA (1998). Accidental Contamination of Human Foods and Animal Feeds: Recommendations for States and Local Agencies. Food and Drug Administration, Rockville, MD.

D.M. Hamby (1991). LADTAP XL: An Improved Electronic Spreadsheet Version of LADTAP II, Westinghouse Savannah River Company, Aiken, SC, WSRC-RP-91-975.

E.P. Hope (1995). Consequence Analysis for Water Pathways for LRWHF SAR Accident Scenarios $(U)$, Westinghouse Savannah River Company, Aiken, SC, S-CLC-G-00039, Rev. 0 .

E.P. Hope (1998). Inter-Office Memorandum to J.M. Thompson, "Transmittal of Surface Water Accidental Releases(U)," Westinghouse Safety Management Solutions, Inc., Aiken, SC, WSMS-M-SAE-98-00173 (5 November 1998).

NCRP (1976). Environmental Radiation and Measurements. National Council on Radiation Protection and Measurements Report No. 50, Bethesda, MD.

A.A. Simpkins (1998). Inter-Office Memorandum to D.R. Marx, "Aqueous Dose Modeling Using LADTAP XL and the Code's Applicability For Use with Emergency Response(U)," Westinghouse Savannah River Company, Aiken, SC, WSRC-SRT-EST-980436 (13 November 1998).

USNRC (1977a). Calculation of Annual Doses to Man from Routine Releases of Reactor Effluents for the Purpose of Evaluating Compliance with 10CFR Part 50 Appendix I. U.S. Nuclear Regulatory Commission Regulatory Guide 1.109, Washington, DC.

USNRC (1977b). Estimating Aquatic Dispersion of Effluents From Accidental and Routine Reactor Releases for The Purpose of Implementing Appendix 1. U.S. Nuclear Regulatory Commission Regulatory Guide 1.113, Washington, DC. 


\subsection{Appendix - Scenarios and Analysis Parameters for the Final Waterborne RELEASE EXAMINATION}

After determination of the appropriate hydrological model, accident events for three areas will be examined. These SRS areas - D-Area, H-Area, and TNX - were agreed upon jointly by Westinghouse Savannah River Company (WSRC), the Department of Energy (DOE) and the States of Georgia and South Carolina, and are documented in WSRC-TR-98-0411 (Clifton 1998). D-Area was selected due to its proximity to the Savannah River and limitations in the ability to mitigate a release from the facility. H-Area contains H-Canyon wastewater and the risk of failure of the Tank Farm engineered berms and subsequent release into outfall $\mathrm{H}-12$. These two aspects made $\mathrm{H}$-Area a viable choice for selection in hydrological modeling. TNX was selected for hydrological modeling because of its close proximity to outfall X-08 and the risk of a potential chemical discharge. Emergency Preparedness Hazard Assessments (EPHAs) and Authorization Basis $(\mathrm{AB})$ documents will be used as references for determination of potential scenarios. Where possible, both $\mathrm{DB}$ and $\mathrm{BDB}$ accidents will be examined for each release area.

The output for the modeled scenarios will be examined for several parameters. Each scenario will be modeled using average, minimum, and maximum flow rates for the Savannah River. Time-to-impact values resulting from the multiple flow rates for various downstream populations will be examined. This will aid in determining the time urgency of an aqueous release. Radionuclide concentrations will be calculated for multiple locations downstream from the release and will be compared with regulatory limits (FDA 1998, EPA 1998). If necessary, ingestion dose resulting from the consumption of contaminated water may be calculated. The accident scenarios examined for each facility area are described below.

\subsection{D and H -Area Scenarios}

Accident scenarios within the EPHAs for the three SRS areas predominantly emphasize the (airborne) plume exposure pathway. For both $\mathrm{D}$ and H-Areas, radiological liquid releases following seismic events may occur as a result of runoff to a water system that feeds into the Savannah River. Within the parameters of the EPHAs, chronic releases consist of a year duration of data collection while acute releases consist of both instantaneous and 24-hour release durations. Both $\mathrm{DB}$ and $\mathrm{BDB}$ accidents will be evaluated for $\mathrm{H}$ and $\mathrm{D}$-Area.

For the H-Area Tank Farm seismic event, the $\mathrm{AB}$ documentation incorporates aqueous releases from F-Area and ITP Wash Water Area since it is assumed that the transfer systems in all areas will be affected. Although aqueous releases from F-Area and ITP Wash Water Area were not chosen for examination, they will be incorporated with $\mathrm{H}$-Area releases for accidents in which $\mathrm{AB}$ documentation includes both areas.

In $\mathrm{H}$-Area, a radiological liquid release outside of containment as a result of a seismic event can reach the Savannah River via liquid runoff pathway to the site boundary from a storm sewer or creek. The liquid water pathways for $\mathrm{DB}$ and $\mathrm{BDB}$ seismic events are calculated based on methodology provided in S-CLC-G-00039 (Hope 1995). The source terms and consequences associated with the DB and BDB seismic events calculations are discussed in S-CLC-G-00108, 
Rev 0 (Cope 1996). The source terms for DB and BDB seismic events are listed in Tables 5 and 6 below.

The DB seismic event is less severe than a $0.2 \mathrm{~g}$ peak horizontal ground acceleration earthquake. Unless the process Structures, Systems, or Components (SSCs) have been designed or are evaluated successfully to the criteria that complies with DOE-STD-1020-94 (DOE 1996), the process SSCs will be assumed to have failed in the DB seismic event. The service systems (e.g. steam, power, water, etc) will be assumed to be in a state that results in the worst-case scenario for the process. Due to the elevation of the F and H-Area Tank farms above the nearby creek, liquid runoff to the creek via a storm sewer is assumed to occur as a result of an SSC failure occurring at or above grade. A slurry composition of up to $50 \%$ by volume sludge and $50 \%$ by volume dilute supernate is considered mobile. Sludge or concentrated supernate outside of the containment is not considered mobile. The source terms for DB seismic event scenarios are given in Table 5.

Table 5 H-Area Design Basis Source Term for Liquid Runoff

\begin{tabular}{|c|c|c|c|}
\hline Isotope & $\begin{array}{c}\text { Runoff \& } \\
\text { Grown }\end{array}$ & Runoff & $\begin{array}{c}\text { Liquid Runoff } \\
\text { Source Term }\end{array}$ \\
\hline Sr-90 & (Ci) & (Ci) & (Ci) \\
\hline Ru-106 & $1.89 \mathrm{E}+03$ & $1.36 \mathrm{E}+02$ & $2.03 \mathrm{E}+03$ \\
\hline Cs-134 & $2.70 \mathrm{E}+05$ & $1.94 \mathrm{E}+04$ & $2.89 \mathrm{E}+05$ \\
\hline Cs-137 & $1.08 \mathrm{E}+06$ & $7.76 \mathrm{E}+04$ & $1.16 \mathrm{E}+06$ \\
\hline Pu-238 & $7.49 \mathrm{E}+06$ & $5.39 \mathrm{E}+05$ & $8.03 \mathrm{E}+06$ \\
\hline
\end{tabular}

The BDB seismic event requires the evaluation of accidents to provide a perspective of the residual risk associated with the operation of the facility. Within the analysis of a BDB seismic event it assumed that the process SSCs of the affected facility would fail. The service systems (e.g. steam, power, water, etc) are assumed to be in a state that results in the worst-case scenario for the process. Due to the elevation of the F and H-Area Tank farms above the nearby creek, liquid runoff to the creek via a storm sewer is assumed to occur as a result of an SSC failure occurring at or above grade. For an SSC failure occurring below grade, liquid transport via the ground system is assumed to occur. It is assumed that no humans are available to mitigate the event. The source term for BDB seismic event scenario is given in Table 6. 
Table 6 H-Area Beyond Design Basis Source Term for Liquid Runoff

\begin{tabular}{|c|c|}
\hline Isotope & $\begin{array}{c}\text { Source Term } \\
\text { (Ci) }\end{array}$ \\
\hline Sr-90 & $2.88 \mathrm{E}+07$ \\
\hline Ru-106 & $9.61 \mathrm{E}+05$ \\
\hline Cs-134 & $3.76 \mathrm{E}+06$ \\
\hline Cs-137 & $2.68 \mathrm{E}+07$ \\
\hline Pu-238 & $1.13 \mathrm{E}+06$ \\
\hline Ce-144 & $1.04 \mathrm{E}+07$ \\
\hline Pu-239 & $8.63 \mathrm{E}+03$ \\
\hline Pu-240 & $6.38 \mathrm{E}+03$ \\
\hline Pu-241 & $1.16 \mathrm{E}+06$ \\
\hline $\mathbf{A m - 2 4 1}$ & $1.01 \mathrm{E}+04$ \\
\hline
\end{tabular}

In the D-Area Heavy Water processing and drum storage facilities, tritium is the only hazardous and radiological material that has the potential to represent any threat of significance to the environment, general public, and onsite personnel. Buildings in the Heavy Water facility are not seismically qualified or hardened to withstand the forces of high winds or tornadoes. Therefore, it is assumed that the buildings fail and result in a maximum release of tritium during the range of natural phenomena hazard (NPH) events. As such, only one accident event will be evaluated for D-Area. The aqueous release source term resulting from high winds, tornadoes, or earthquakes is $2.58 \times 10^{+6}$ curies of tritium.

\section{$9.2 \quad$ TNX Scenarios}

The only large amounts of radioactive materials at TNX are solutions of uranyl nitrate stored in two tanks in the vicinity of 677-T. The TNX EPHA (S-EHA-T-00001) has an inventory of less than 2 curies Uranyl nitrate solution. Within the EPHA the radionuclides were screened in accordance with the guidance of EMPP 6Q-001 where the threshold values of 10 CFR 30.72 are utilized. The total quantity of depleted uranium is $1569 \mathrm{~kg}$. The Hazard Assessment Document (HAD) analyzed the solution as natural uranium (99.27\% U-238, 0.72\% U-235, and $5.5 \times 10^{-3} \%$ U-234). The total curie content of the two tanks is approximately 1.25 Curies of uranium. The TNX inventory is scheduled to be transferred to F or H-Area in the near future. 